\title{
Comparative Evaluation of the Nutritional, Physical and Sensory Properties of Beef, Chicken and Soy Burgers
}

\author{
ADENIYI Paulina O. ${ }^{1}$ \\ OBATOLU Veronica A. ${ }^{2}$ \\ KEHINDE Hammed A. ${ }^{3}$
}

\author{
Institute of Agricultural Research and Training, Obafemi Awolowo University, Moor Plantation, Apata, Ibadan, Nigeria \\ ${ }^{2}$ Email:dovinadenivi@yahoo.com Tel:+2347068839933 \\ 2Email:veromum1@yahoo.co.uk Tel:+2348033632715 \\ ${ }^{3}$ Federal College of Agriculture, Moor Plantation, Apata, Ibadan, Nigeria \\ ( Corresponding Author)
}

\begin{abstract}
The sporadic technological advancement witnessed worldwide since the beginning of the twenty first century has encouraged civilization and urbanization culminating into changes in lifestyle from active to sedentary globally. People now prefer instant foods and eating out in different food service units to home cooked meals. Burger is a special delicacy which is seldom prepared at home but commonly purchased from restaurants. The need to encourage human consumption of soybean cannot be over emphasized due to the unrivalled nutritional and health benefits derivable from it especially in combating some communicable diseases, the epidemic of which is becoming alarming globally, hence, harnessing soybean potentials in the production of burger is of pertinent importance. This experimental study was therefore designed to compare the nutritional, physical and sensory properties of soy burger with those of the conventional beef and chicken burgers. Soy cheese was prepared from soybeans using appropriate culinary procedure. Equal portions of minced beef, minced chicken and soy cheese were processed into burgers using basic recipe. Beef, chicken and soy burgers were subjected to proximate, thiamine, riboflavin, cholesterol, colour, texture and sensory evaluation using standard methods. Mean data were compared using Analysis of Variance at $\mathrm{p} \leq$ 0.05. Protein content (Dry Weight Basis) for Beef burger (BB), Chicken Burger (CB) and Soy Burger $(\mathrm{SB})$ were $57.87,50.36$ and 53.89\% respectively. In similar sequence fat content were $10.02(\mathrm{BB}) 10.15(\mathrm{CB})$ and $8.58(\mathrm{SB})$. SB was significantly higher than the other two samples in crude fibre, riboflavin and niacin while its cholesterol content was negligible. There was no significant difference between $\mathrm{SB}$ and $\mathrm{CB}$ in lightness and redness while the values for yellowness were 10.60, 25.12 and 18.25 for BB, CB AND SB respectively. In the same vein there was no significant difference in chewiness, cohesiveness and springiness of the three burger samples. For overall acceptability BB was most acceptable followed by SB and then CB. The nutritional, physical and sensory properties of soy burger were comparable to that of beef and chicken burgers, hence, soy burger may compete favourably with the conventional types of burger and is hereby presented as a cholesterol-free alternative with higher health benefits suitable for all even vegans. Household and commercial production and consumption of soy burger is hereby recommended.
\end{abstract}

Keywords: Beef burger, Chicken burger, Soy burger.

Citation | ADENIYI Paulina O.; OBATOLU Veronica A KEHINDE Hammed A (o018) Comparative Evaluation of the Nutritional, Physical and Sensory Properties of Beef, Chicken and Soy Burgers. Agriculture and Food Sciences Research, 5(2): 57-63. History:

Received: 23 April 2018

Revised: 9 May 2018

Accepted: 14 May 2018

Published: 16 May 2018

Licensed: This work is licensed under a Creative Commons

Attribution 3.0 License (c) $)$

Publisher: Asian Online Journal Publishing Group
Contribution/Acknowledgement: Both authors contributed to the conception and design of the study.

Funding: This study received no specific financial support.

Competing Interests: The authors declare that they have no conflict of interests.

Transparency: The authors confirm that the manuscript is an honest, accurate, and transparent account of the study was reported; that no vital features of the study have been omitted; and that any discrepancies from the study as planned have been explained.

Ethical: This study follows all ethical practices during writing.

\section{Contents}

1. Introduction

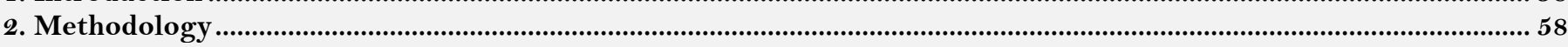

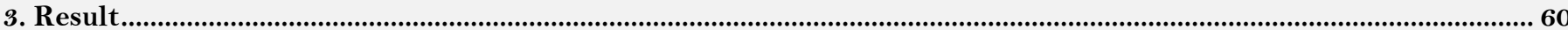

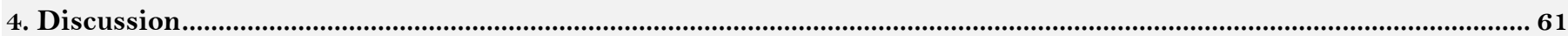

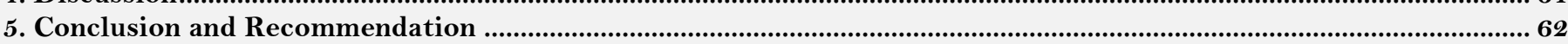

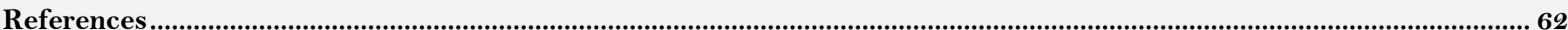




\section{Introduction}

The pros and cons of any concept commonly go hand in hand. If the pros outweigh the cons the concept may be considered desirable and helpful. The same is witnessed in the sporadic technological advancement which was being experienced since the beginning of the twenty first century. The affirmation of the very rapid advancement in technology in the $21^{\text {st }}$ century has been reported [1]. It has enhanced good security while concomitantly threatening adequate security globally [1]. It has encouraged sedentary lifestyle which has increased the epidemic of some non communicable diseases which may be fondly referred to as 'diseases of comfort' the overall causes of death by the $22^{\text {nd }}$ century [2]. Sedentary lifestyle predisposes an individual to chronic diseases such as cancer, cardiovascular disease, Type 2 diabetes mellitus and osteoporosis and may be regarded as 'civilization diseases [3]. It is therefore imperative that feasible measures should be designed and actualized to cushion the adverse effect of technological advancement and civilization on human health and development. One of such measures is to influence food choices and habit towards the consumption of adequately healthy foods which are naturally endowed to combat or prevent these civilization diseases or diseases of comfort.

Soybean is of unrivalled nutritional and health benefits. It is the only plant source of complete protein and competes favourably with animal protein [4]. The ability of soybean consumption to prevent heart disease, breast cancer, prostate cancer and osteoporosis has been well affirmed by both old and recent scientific reports [5-9]. All these ascertained the ability of soybean in preventing the so called civilization diseases or diseases of comfort; hence, it is of pertinent importance to encourage the consumption of soybean globally.

Burger, the origin of which is traceable to Germany and America, is now a special delicacy of international acceptance and reception, that is, it is now commonly consumed and enjoyed by people all over the world. Harnessing the global acceptability of burger in encouraging the consumption of soybean is therefore a thoughtful, feasible and viable approach in combating the alarming epidemic of civilization diseases. Burger is commonly prepared with minced beef or chicken but other meat sources such as turkey, ostrich, deer, buffalo, sheep, etc may be used [10]. A burger is a sandwich of cooked patties of minced meat, usually beef, inside a sliced bread roll or burger bun and may be accompanied with cheese, lettuce, onion, tomato, bacon and pickles while condiment such as mayonnaise, mustard, ketchup, barbecue sauce may be added. The meat patty may be cooked by pan roasting, pan frying, grilling or flame broiling [10]. Meat-like product has been produced from Tofu (Soy cheese) using food extruder [11] a food processing invention which may be expensive and may not be affordable for household and small/medium scale commercial production and consumption. Preparation of burger from soybean using Tofu is an approach of producing meat-like product from soybean, the process of which is simple, affordable and easily accessible, hence, this study was designed to compare the nutritional, physical and sensory properties of soy burger with that of the conventional beef and chicken burgers with the view of producing soy burger that can compete favorably with beef and chicken burgers in these parameters so as to encourage the consumption of the wonder bean towards alleviating the incidence of civilization diseases globally.

\section{Methodology}

\subsection{Collection of Materials}

Soybeans (TGX-1740) were collected from the seed store of the Institute of Agricultural Research and Training, Obafemi Awolowo University, Apata, Ibadan, Nigeria. Minced beef and chicken were purchased from Shoprite supermarket, Palm Mall, Ring Road, Ibadan. Breadcrumbs was prepared from oven dried sliced bread (My Joy, Ibadan, Nigeria). Other ingredients were purchased from local market in Apata, Ibadan.

\subsection{Preparation of Soy Cheese}

Soybeans were cleaned manually and soaked in water for 16hours at ambient temperature after which the water was decanted and the beans were washed with clean water. This was then allowed to simmer in water for 5 minutes. The hot water was drained off and the beans were wet-milled using plate attrition mill (Amuda Plate Mill, India). The paste was diluted with water and sieved using cheese cloth. The extract (soymilk) was allowed to boil and while still boiling sour steep water was added in ration $7: 1(\mathrm{v} / \mathrm{v})$ for soymilk: steep water. The curd separated immediately and further boiling for 30 minutes was done after which this was poured in a cheese cloth and allowed to drain with a heavy load placed on it.

\subsection{Preparation of Burger Samples}

The three burger samples were prepared using basic recipe. Ingredients used are expressed in Table 1.

Table-1. Basic ingredients for the preparation of beef, chicken and soy burgers

\begin{tabular}{l|l|l|l}
\hline Ingredients & Beef Burger & Chicken Burger & Soy Burger \\
\hline Meat & Minced beef $(500 \mathrm{~g})$ & Minced chicken $(500 \mathrm{~g})$ & Soy cheese $(500 \mathrm{~g})$ \\
\hline Wheat flour & $50 \mathrm{~g}$ & $50 \mathrm{~g}$ & $50 \mathrm{~g}$ \\
\hline Bread crumbs & $50 \mathrm{~g}$ & $50 \mathrm{~g}$ & $50 \mathrm{~g}$ \\
\hline Bouillon cube (Knorr) & $1 \mathrm{cube}$ & $1 \mathrm{cube}$ & $1 \mathrm{cube}$ \\
\hline Bell pepper and onion paste & $20 \mathrm{ml}$ & $20 \mathrm{ml}$ & $20 \mathrm{ml}$ \\
\hline Salt & $2 \mathrm{~g}$ & $2 \mathrm{~g}$ & $2 \mathrm{~g}$ \\
\hline Margarine (for greasing tray) & $5 \mathrm{~g}$ & $5 \mathrm{~g}$ & $5 \mathrm{~g}$ \\
\hline Source: Aidells $[10]$ & &
\end{tabular}

Ingredients were gently mixed together and divided into small portions which were shaped into flat forms of about $1.5 \mathrm{~cm}$ thickness. These were placed in greased aluminium trays and positioned under the grill and allowed to grill for 20 minutes for each side to give the three burger samples. These were the subjected to protein, fat, ash, fiber, carbohydrate, thiamine, riboflavin, niacin, cholesterol, color, texture and sensory evaluation. 


\subsection{Moisture Content Determination}

This was determined using the air oven method [12]. A known weight of the sample (3g) was put in a washed, dried and cooled crucible and this was dried at $103^{\circ} \mathrm{C}$ until a constant weight was obtained. This was allowed to cool in a desiccator and the difference in weight was used to calculate the moisture content.

\subsection{Protein Content Determination}

The crude protein content was determined using the micro Kjeldahl method as described by Kirk and Sawyer [12]. A tablet of Kjeldahl catalyst was added to a known weight of the sample (0.2077g) in a long necked Kjedahl flask. This was heated in a fume cupboard with $25 \mathrm{~cm}^{3}$ of concentrated $\mathrm{H}_{2} \mathrm{SO}_{4}$ until a clear solution was obtained. This was cooled, poured into a $10 \mathrm{~cm}^{3}$ volumetric flask and made up to mark with distilled water after which $10 \mathrm{ml}$ of this was measured into a distillation set. $5 \mathrm{~cm}^{3}$ of boric acid was pipette into a $100 \mathrm{ml}$ conical flask and placed at the receiving end of the distillation unit with the delivery tube completely dipped into the flask. $40 \% \mathrm{NaOH}$ was used to liberate ammonia out of the digest into the boric acid under alkaline condition and this was titrated against $0.1 \mathrm{~N} \mathrm{HCl}$ until the first permanent color change was observed. Blank sample was run through the procedure and the titer value was used to correct the titer value for the test samples. The protein content was calculated thus:

$\% \mathrm{~N}=\underline{\text { Molarity of } \mathrm{HCl} \times \text { (sample titre- blank titre) } \mathrm{x} 0.014 \times \mathrm{DF} \times 100}$

Weight of sample

$\% \mathrm{~N}$ was converted to the percentage crude protein by multiplying by 6.25

\subsection{Crude Fat Content Determination}

The fat content was determined using Soxhlets extraction method as described by Kirk and Sawyer [12]. A known weight of the sample $(2 \mathrm{~g})$ was put into a weighed filter paper and folded neatly. This was put inside a preweighed thimble $\left(\mathrm{W}_{1}\right)$. The thimble with the sample $\left(\mathrm{W}_{2}\right)$ was inserted into the soxhlets apparatus and extraction was carried out under reflux with petroleum ether $\left(40^{\circ} \mathrm{C}-60^{\circ} \mathrm{C}\right.$ boiling range) or 6 hours. At the end of the extraction, the thimble was dried in the oven for about for about 30 minutes at $100^{\circ} \mathrm{C}$ to evaporate the solvent and thimble was cooled in a desiccator and later weighed $\left(\mathrm{W}_{3}\right)$. Crude fat content of the sample was calculated thus:

$\%$ Fat $=\frac{\text { Loss in weight of sample } \times 100}{\text { Original weight of the sample }}=\frac{\mathrm{W}_{2}-\mathrm{W}_{3}}{\mathrm{~W}_{2}-\mathrm{W}_{1}} \times 100$

\subsection{Ash Content Determination}

The ash content denotes the total amount of minerals present in the products. This was determined using the method as described by Kirk and Sawyer [12]. A known weight $(1.5 \mathrm{~g})$ of finely ground sample was weighed into clean and dry previously weighed crucible with lid $\left(\mathrm{W}_{1}\right)$. The sample was ignited over a low flame to char the organic matter with lid removed. The crucible was then placed in muffle furnace at $600^{\circ} \mathrm{C}$ for 6 hours until it was turned to ash completely. This was then transferred directly to desiccators to cool and was later weighed $\left(\mathrm{W}_{2}\right)$.

$$
\% \text { Ash }=\frac{\mathrm{W} 2-\mathrm{W} 1}{\text { Weight of sample }} \times 100
$$

\subsection{Crude Fibre Determination}

The crude fibre was determined using the method as described by Kirk and Sawyer [12]. Two hundred milliliters $(200 \mathrm{ml})$ of freshly prepared $1.25 \% \mathrm{H} 2 \mathrm{SO} 4$ was added to a known weight $(3 \mathrm{~g})$ of the residue obtained from fat extraction and this was boiled for 30 minutes and then filtered after which the residue was washed until it was free from acid. The residue was transferred quantitatively into a digestion flask and $1.25 \% \mathrm{NaOH}$ was added after which this was boiled for 30 minutes. This was followed by filtration and the residue was then washed with methylated spirit and then petroleum ether to be free of alkali. This was then allowed to drain and the residue was transferred to a silica dish (previously ignited at $600^{\circ} \mathrm{C}$ and cooled). The dish and its content were dried to constant weight at $105^{\circ} \mathrm{C}$. The organic matter of the residue was burnt by igniting for 30 minutes in a muffle furnace at $\left.600^{\circ} \mathrm{C}\right)$. The residue was cooled and weighed while the loss on ignition was reported as crude fibre.

\subsection{Carbohydrate Content Determination}

This was calculated by difference of all other nutrients from 100.

\subsection{Thiamine, Riboflavin and Niacin determination}

These B vitamins content were determined using the method as described Kirk and Sawyer [12].

\subsection{Thiamine Determination}

Method as described by Kirk and Sawyer [12] was used Fifty milliliters (50ml) of 50\% methanol and 50ml of $17 \%$ sodium carbonate was added to $1 \mathrm{~g}$ of the sample in order to extract the vitamin. This was then filtered after which Folins-Denis reagent was added. This was allowed to cool until a bluish color was developed and absorbance was read in a spectrophotometer at $415 \mathrm{~nm}$. A standard curve was prepared using the data obtained with Tannic acid in place of the sample and the values for the sample were extrapolated from this curve.

\subsection{Riboflavin Determination}

The method as described by Kirk and Sawyer [12] was used. To 0.5g of the sample 30ml of Dichloroethane and $30 \mathrm{ml}$ of $30 \% \mathrm{HCl}$ were added. This was followed by the addition of $50 \mathrm{ml}$ of ammonium hydroxide solution after which filtration was carried out and later the absorbance was read at $415 \mathrm{~nm}$. A standard curve was constructed using the data obtained from the use of standard Riboflavin in place of the sample and the curve was used to extrapolate the values for the samples. 


\subsection{Niacin Determination}

Method as described by Kirk and Sawyer [12] was used. Niacin was extracted by autoclaving the sample (1g) with $0.75 \mathrm{~g}$ calcium hydroxide and $20 \mathrm{ml}$ deionised water at $121^{\circ} \mathrm{C}$ for 30 minutes. The mixture was diluted with 30 $\mathrm{ml}$ of water, mixed thoroughly and allowed to cool after which it was centrifuged at $0^{\circ} \mathrm{C}$ and $2500 \mathrm{rpm}$ for 15 minutes. A $15 \mathrm{ml}$ sample of the supernatant was adjusted to $\mathrm{pH} 7$ with aqueous oxalic acid. The resulting suspension was centrifuged at $2500 \mathrm{rpm}$ for 10 minutes to precipitate the calcium oxalate and the absorbance was measured at $650 \mathrm{~nm}$. A standard curve was constructed using the absorbance readings obtained from the reference niacin solutions in place of the sample and this was used to extrapolate the niacin content of the samples.

\subsection{Cholesterol Determination}

This was carried out using the Liebermann-Burchard reaction as described by Kirk and Sawyer [12]. A small quantity of the sample was added to $1 \mathrm{ml}$ of chloroform and this was stirred with magnetic stirrer. A combination of $40 \mathrm{ml}$ acetic anhydride and $2 \mathrm{ml}$ conc. $\mathrm{H}_{2} \mathrm{SO}_{4}$ was added. This was later poured into distilled water and a green coloration was observed the absorbance of which was read with a spectrophotometer at $640 \mathrm{~nm}$. The concentration was extrapolated from a calibration curve.

\subsection{Color Analysis}

The intensity of the color in the samples (Lightness-L, Redness-a, and Yellowness-b) was determined using a colorimeter (Chroma meter CR-410, Japan). The samples were set in the sensor and the value was read from the reader.

\subsection{Texture Analysis}

Cylindrical samples of $10 \mathrm{~mm}$ diameter and $12 \mathrm{~mm}$ height were cut from the burger samples. The texture properties of the samples were determined using a texture analyzer (TexVol TVT 300 PH, Sweden). The texture parameters determined were: hardness, chewiness, cohesiveness and stringiness..

\subsection{Sensory Evaluation}

Burger samples were subjected to sensory evaluation with a total of 20 trained taste panelists using a 7 point hedonic scale with 1 denoting 'dislike extremely' and 7 denoting 'like extremely'. The following sensory properties were evaluated: texture, appearance, aroma, taste and overall acceptability.

\section{Result}

Data are expressed in mean \pm standard deviation.

Table-2. Proximate composition of beef, chicken and soy burgers in Dry Weight Basis (DWB)

\begin{tabular}{l|l|l|l|l|l}
\hline Samples & Protein (\%) & Fat (\%) & Ash (\%) & Crude fiber (\%) & Carbohydrate (\%) \\
\hline BB & $57.87 \mathrm{a} \pm 0.15$ & $10.02 \mathrm{a} \pm 0.15$ & $5.11 \mathrm{a} \pm 0.10$ & $1.29 \mathrm{c} \pm 0.58$ & $25.71 \mathrm{c} \pm 1.10$ \\
\hline $\mathrm{CB}$ & $50.36 \mathrm{c} \pm 1.25$ & $10.15 \mathrm{a} \pm 2.03$ & $5.04 \mathrm{a} \pm 0.15$ & $1.80 \mathrm{~b} \pm 0.22$ & $32.65 \mathrm{a} \pm 0.25$ \\
\hline SB & $53.89 \mathrm{~b} \pm 0.20$ & $8.58 \mathrm{~b} \pm 1.15$ & $4.27 \mathrm{~b} \pm 0.21$ & $2.88 \mathrm{a} \pm 0.10$ & $30.38 \mathrm{~b} \pm 0.36$ \\
\hline
\end{tabular}

BB was highest in protein content followed by SB and then CB. Soy burger was least in ash and fat content but contained the highest quantity of crude fibre.

Table-3. Vitamin and cholesterol composition of beef, chicken and soy burgers in DWB $(\mathrm{mg} / 100 \mathrm{~g})$

\begin{tabular}{l|l|l|l|l}
\hline Samples & Thiamine & Riboflavin & Niacin & Cholesterol \\
\hline $\mathrm{BB}$ & $0.98 \mathrm{a} \pm 0.02$ & $0.51 \mathrm{~b} \pm 0.05$ & $1.04 \mathrm{a} \pm 0.06$ & $2.99 \mathrm{~b} \pm 0.15$ \\
\hline $\mathrm{CB}$ & $0.75 \mathrm{~b} \pm 0.15$ & $0.33 \mathrm{c} \pm 0.03$ & $0.57 \mathrm{c} \pm 0.10$ & $3.58 \mathrm{a} \pm 0.21$ \\
\hline $\mathrm{SB}$ & $0.13 \mathrm{c} \pm 0.01$ & $0.96 \mathrm{a} \pm 0.06$ & $0.85 \mathrm{~b} \pm 0.05$ & $0.03 \mathrm{c} \pm 0.01$ \\
\hline Note: Data in the same column with different alphabets are significantly different (p $\leq 0.05) ;$ BB-Beef Burger; CB- Chicken Burger; SB- Soy Burge
\end{tabular}

Thiamine, riboflavin and niacin content of the three burger samples are significantly different. Soy burger was highest in riboflavin and niacin content but contained the least quantity of thiamine. The cholesterol content of soy burger was negligible compared to that of beef and chicken burgers.

Table-4. Colour properties of beef, chicken and soy burgers.

\begin{tabular}{l|l|l|l}
\multicolumn{4}{c}{ Table-4. Colour properties of beef, chicken and soy burgers. } \\
\hline Samples & L (Lightness) & a (redness) & b (yellowness) \\
\hline BB & $48.31 \mathrm{~b} \pm 0.39$ & $18.45 \mathrm{a} \pm 0.12$ & $10.60 \mathrm{c} \pm 0.80$ \\
\hline $\mathrm{CB}$ & $51.28 \mathrm{a} \pm 1.28$ & $10.58 \mathrm{~b} \pm 2.13$ & $25.12 \mathrm{a} \pm 0.59$ \\
\hline SB & $50.09 \mathrm{a} \pm 1.34$ & $9.54 \mathrm{~b} \pm 1.35$ & $18.25 \mathrm{~b} \pm 0.34$ \\
\hline Note: Data in the same column with different alphabets are significantly different $(\mathrm{p} \leq 0.05)$; BB-Beef Burger; CB- Chicken Burger; SB- Soy Burge
\end{tabular}

Soy burger was not significantly different from chicken burger in lightness and redness while for yellowness beef burger had the least value followed by soy burger and then chicken burger. 
Table-5. Texture properties of beef, chicken and soy burgers

\begin{tabular}{l|l|l|l}
\hline Parameter & BB & CB & SB \\
\hline Hardness (N) & $16.54 \mathrm{a} \pm 0.64$ & $17.71 \mathrm{~b} \pm 1.21$ & $15.40 \mathrm{c} \pm 1.14$ \\
\hline Chewiness (N.mm) & $7.80 \mathrm{a} \pm 1.21$ & $7.12 \mathrm{a} \pm 0.20$ & $7.24 \mathrm{a} \pm 0.68$ \\
\hline Cohesiveness & $0.66 \mathrm{a} \pm 1.23$ & $0.62 \mathrm{a} \pm 0.12$ & $0.65 \mathrm{a} \pm 0.24$ \\
\hline Springiness (mm) & $0.81 \mathrm{a} \pm 1.42$ & $0.78 \mathrm{a} \pm 0.45$ & $0.72 \mathrm{ab} \pm 0.25$ \\
\hline Note: Data in the same row with different alphabets are significantly different (p $\leq 0.05) ;$ BB-Beef Burger; CB- Chicken Burger; SB- Soy Burger
\end{tabular}

The three burger samples were not significantly different in chewiness, cohesiveness and but differed significantly in hardness and springiness.

Table-6. Scores for the sensory properties of beef, chicken and soy burgers

\begin{tabular}{l|l|l|l|l|l}
\hline Samples & Texture & Appearance & Aroma & Taste & Overall acceptability \\
\hline BB & $6.43 \mathrm{a} \pm 0.58$ & $6.77 \mathrm{a} \pm 0.06$ & $6.80 \mathrm{a} \pm 0.10$ & $6.97 \mathrm{a} \pm 0.06$ & $6.90 \mathrm{a} \pm 0.10$ \\
\hline $\mathrm{CB}$ & $5.60 \mathrm{~b} \pm 0.10$ & $6.87 \mathrm{a} \pm 0.12$ & $6.10 \mathrm{~b} \pm 023$ & $4.50 \mathrm{c} \pm 0.10$ & $5.07 \mathrm{~b} \pm 0.12$ \\
\hline SB & $6.07 \mathrm{a} \pm 0.12$ & $6.43 \mathrm{a} \pm 0.06$ & $6.15 \mathrm{~b} \pm 0.28$ & $6.67 \mathrm{~b} \pm 0.12$ & $6.37 \mathrm{a} \pm 0.15$ \\
\hline
\end{tabular}

Soy burger was not significantly different from beef burger in texture and overall acceptability. In the same vein, soy burger was comparable to chicken burger in aroma while there existed no significant difference the appearance of the three burger samples.

\section{Discussion}

Soy burger was significantly higher in protein content than chicken burger while beef burger had the highest value (Table 2). Since same ingredients were used in preparing the burgers, except the meat or meat alternative sources, the difference in composition may be attributed to the meat sources. Raw lean beef was observed to contain $30.61 \%$ protein and $3.49 \%$ fat at $64.8 \%$ moisture which translates to $86.93 \%$ protein and $9.91 \%$ fat in dry weight basis [13]. In the same vein, lean chicken meat of the breast and thigh contained an average of $21.1 \%$ protein at $71.1 \%$ moisture content and this translates to $73.1 \%$ crude protein in dry weight basis [14]. Soy bean on the other hand contained an average of $48.5 \%$ protein in high protein seeds and $41.5 \%$ in normal protein seeds at $15 \%$ moisture content thus translating to $57.05 \%$ protein in high protein seeds and $48.82 \%$ in normal protein seeds [15]. It can therefore be inferred from these that in dry weight basis the protein content of lean beef, chicken and soybean are $86.96,73.01$ and $57.05 \%$ respectively.

However, in this study chicken burger had the least protein content while the highest value was observed in beef burger. This implies that tofu (soy cheese) is a rich in protein and this has been ascertained by past study [16] coupled with the fact that the soybean variety used in this study was of exceptionally high protein content. This may not be surprising since it is an improved variety. This may also be as a result of the lower protein content of the minced chicken used which may be traceable to genetic, dietary and other environmental factors. Soy burger contained the least quantity of fat and ash while there were no significant differences in values for beef burger and chicken burger. The lower fat content of soy burger may be expected since this ultimately gave allowance for the high protein content as earlier discussed.

Soy burger was significantly higher than both beef and chicken burgers in crude fibre. This is quite expected since it is from plant source compared with the other two conventional burgers which are animal-based foods. Chicken burger contained the highest quantity of carbohydrate followed by soy burger and then beef burger. The major common sources of carbohydrate in the burgers produced are wheat flour and bread crumbs. The proximate composition of beef burger observed in this study was in disparity with that of Carvalho, et al. [17] who reported a protein, fat, ash and carbohydrate content of 40.23, 42.50, 8.94 and $8.23 \%$ respectively in dry weight basis. This may be as a result of variation in ingredients used. Similarly, chicken burger was observed to contain in dry weight basis $29.91 \%$ protein, $52.61 \%$ fat and $7.48 \%$ ash [18]. The lower protein and higher fat content of this compared with that of the chicken burger observed in this study may be as a result of differences in the ingredients used.

Beef burger was highest in thiamine followed by chicken burger while soy burger was too low in this vitamin (Table 3). On the other hand soy burger was significantly higher than beef and chicken burgers in riboflavin while the highest niacin content was observed in beef burger with chicken burger having the least value (Table 3). The cholesterol content of soy burger was negligible compared with that of beef and chicken burgers. The differences in these nutritional composition, as earlier stated, was mainly attributed to the difference meat or meat alternative used since all other ingredients used were the same in type and quantity. Beef was reported to contain $1.2 \mathrm{mg} / 100 \mathrm{~g}$ thiamine, $1.3 \mathrm{mg} / 100 \mathrm{~g}$ riboflavin and $16 \mathrm{mg} / 100 \mathrm{~g}$ niacin [19] chicken meat contained $0.09 \mathrm{mg} / 100$ thiamine, $0.16 \mathrm{mg} / 100 \mathrm{~g}$ riboflavin and $7 \mathrm{mg} / 100 \mathrm{~g}$ niacin $[20]$.

The thiamine, riboflavin and niacin content of soybean were; $0.66,0.22$ and $2 \mathrm{mg} / 100 \mathrm{~g}$ respectively [20]. Judging from these data, beef burger should contain the highest quantity of these vitamins followed by soy burger while chicken burger is expected to be higher in niacin than soy burger. However, the result observed in this study showed that beef burger contained highest quantity of thiamine and niacin only. This may be as a result of variation in the diet of the cattle used. Unexpectedly, chicken burger was higher than soy burger in thiamine though the frmer contained the least quantity of riboflavin ad niacin as expected. The unexpectedly low thiamine content of soy burger may be as a result of loss of this vitamin with 'whey' water that was drained from the bean curds to obtain soy cheese.

For color analysis soy burger was not significantly different from chicken burger in lightness and redness. Beef burger had the highest value for redness (Table 4) and least values for lightness and yellowness. This may be as a result of the higher myoglobin constituent of beef compared with chicken [21] and which is absent in soybean. This myoglobin commonly coverts to red oxymyoglobin on exposure to air and when cooked it is converted to brown metmyoglobin. 
The color properties of beef burger observed in this study were different from that of past scientific report. Carvalho, et al. [17] observed the lightness, redness and yellowness values for beef burger to be 44.7, 3.3 and 10.6 respectively. In the same vein, Bestos, et al. [22] observed beef burger to have the following values for lightness, redness and yellowness respectively; 32.09, 5.70 and 4.46. The disparity of these from the observation in this study may be as a result of differences in ingredients used since only basic ingredients were used in this study in order to minimize the influence of confounding variables. Variation in color analyzer used may also be responsible for this. On the other hand, the color properties of chicken burger in this study were in close proximity with that observed by Uran and Yilmaz [18] who reported values for lightness, redness and yellowness of chicken burger to be 50.29, 9.07 and 22.12 respectively. Similarity in materials and method used as well as the colour analyzer may be responsible for this.

All the three burger samples were similar in chewiness and cohesiveness (Table 5). For chewiness, beef burger had the highest value followed by soy burger and then chicken burger while for cohesiveness followed similar trend. The three burgers produced were significantly different in hardness with chicken burger having the highest value followed by beef burger and then soy burger.

Springiness, which is the ability of the sample to resume its original shape when deforming force is exerted and removed, was observed to be highest in beef burger and least in soy burger. There existed no significant difference between beef burger and soy burger in this texture parameter. In overall, soy burger was comparable to beef and chicken burgers in texture parameters since there were close proximity of values even where significant difference existed. Texture parameters from past findings are comparable to that observed in this study. Carvalho, et al. [17] reported beef burger with hardness, chewiness, cohesiveness and springiness to be 15.38, 8.23, 0.69 and 0.78 respectively while in this study these parameters were 17.51, 6.58, 0.65 and 0.57 (Table 5). The close proximity of the values observed in this study with that of the past study could be as a resultant effect of similarity in the methods used in the preparation of the beef burgers.

For evaluation of sensory properties, the three burger samples did not differ significantly in appearance and were judged to be equally liked. For texture there was similarity in the likeness of beef and soy burgers and these were more preferred to chicken burger. The aroma of the three burger samples were liked but beef burger was most preferred while there existed no significant difference in chicken and soy burgers. The taste of beef and soy burgers were more preferred than that of chicken burger. In overall evaluation, beef and soy burgers were equally acceptable and more preferred to chicken burger. These show that soy burger can compete favorably in sensory properties with beef and chicken burgers

\section{Conclusion and Recommendation}

Soy burger is comparable to beef and chicken burgers in proximate composition and texture properties. It is higher in riboflavin and niacin than the two conventional burgers types with negligible cholesterol content. Furthermore soy burger is similar to chicken burger in color attributes. It is more preferred than chicken burger in taste, texture and overall acceptability and is at par with beef burger in overall acceptability. Soy burger can therefore compete favorably with beef and chicken burgers, hence, may be presented as a cholesterol-free healthier alternative suitable for all, even strict vegetarians. Household and commercial production and consumption is hereby encouraged.

\section{References}

[1] A. Mallik, "Technology and security in the 21st century, a demen-side perspective in SIPRI (Stockholm International Peace Research Institute)," Research Report, No 20, Oxford University Press, New York, 2004.

[2] B. C. K. Choi, D. J. Hunter, W. Tsou, and P. Sainsbury, "Diseases of comfort: Primary cause of death in the 22 nd century," Journal of Epidemiology and Community Health, vol. 59, pp. 1030-1034, 2005. View at Google Scholar | View at Publisher

[3] J. Kruk, "Health and economic costs of physical inactivity," Asian Pacific Journal of Cancer Prevention, vol. 15, pp. 7499-7503, 2014. View at Google Scholar $\mid$ View at Publisher N. Daniel, "A review on replacing fish meal in aqua feeds using plant protein sources," International Journal of Fisheries and Aquatic Studies, vol. 6, pp. 164-1 79, 2018. View at Google Scholar

[5] S. Barnes, "Evolution of the health benefits of soy isoflavones," Experimental Biology and Medicine, vol. 217, pp. 386-396, 1998. View at Google Scholar | View at Publisher

[6] M. J. Messina, "Legumes and soybeans: Overview of their nutritional profiles and health effects," American Journal of Clinical Nutrition, vol. 70, pp. 439s-450s, 1999. View at Google Scholar | View at Publisher

[7] M. Friedman and D. L. Brandon, "Nutritional and health benefits of soy proteins," Journal of Agricultural and Food Chemistry, vol. 49, pp. 1069-1086, 2001. View at Google Scholar | View at Publisher

[8] C. R. D’Adamo and A. Sahin, "Soy foods and supplementation: A review of commonly perceived health benefits and risks," Alternative Therapy in Health and Medicine, vol. 20, pp. 39-51, 2014.

[9] M. Messina, "Soy and health update: Evaluation $\mathrm{f}$ the clinical and epidemiologic literature," Nutrients, vol. 8, pp. 754, 2016. View at Google Scholar | View at Publisher B. Aidells, The great meat cook book: Everything you need to know to buy and cook today's meat. Ed: Rano A.M. New York: Houghton Harcourt Publishing Company, 2012.

Y. Akiyam, S. Yoshihushi, and I. Sakauchi, Processing tofu intomea-like texture. Japan: US4880659A, 1985.

R. S. Kirk and R. Sawyer, Pearson's composition and analyses of foods, 9th ed. Longman: United Kingdom, 2005.

A. Rodaz-Gonzalez, I. L. Larsen, B. Uttaro, M. Juarez, J. Parslow, and J. L. Alhus, "Determination of optimum oven cooking procedures for lean beef products," Food Science and Nutrition, vol. 3, pp. 475-485, 2015. View at Google Scholar $\mid$ View at Publisher

[14] I. Giannenas, A. Tzora, E. Bonos, I. Sarakatslanos, A. Karamoutslos, F. Anastaslou, and L. Skoufos, "Effects of dietary oregano essential oil, laurel essential oil and attapulgite on chemical composition, oxidative stability, fatty acid profile and mineral content of chicken breast and thigh meat," European Poultry Science, vol. 80, pp. 1-18, 2006. View at Google Scholar

[15] E. Y. Hwang, Q. Song, G. Jia, J. E. Specht, D. L. Hyten, J. Costa, and P. B. Cregan, "A genome-wide association study of seed protein and oil content of soybean," BioMed Central Genomics, vol. 15, p. 1, 2014. View at Google Scholar $\mid$ View at Publisher

[16] K. Anbarasu and G. Vijayalakshmi, "Improved shelf life of protein-rich tofu using Ocimum sanctum (tulsi) extracts to benefit Indian rural population," Journal of Food Science, vol. 72, pp. M300-M305, 2007. View at Google Scholar $\mid$ View at Publisher

[17] G. R. Carvalho, T. M. G. Milam, N. R. R. Trinca, L. Y. Nagai, and A. C. S. Barretto, "Textures soy protein, collagen and maltodextrin as extenders to improve the physicochemical and sensory properties of beef burger," Food Science and Technology, vol. 37, pp. 10-16, 2017. View at Google Scholar

[18] H. Uran and I. Yilmaz, "A research on determination of quality characteristics of chicken burgers produced with transglutaminase supplementation," Food Science and Technology, (AHEAD), pp. 0-0, 2017. View at Google Scholar | View at Publisher 
[19] P. Williams, "Nutritional composition of red meat," Nutrition and Dietetics, vol. 64, pp. S113-S1 19, 2007. View at Google Scholar $\mid$ View at Publisher

R. A. Sanusi, I. O. Akinyele, H. N. Ene-Obong, and V. N. Enujiugha, Nigerian food composition table. Nigeria: Straight-Gate Publishers, 2017.

[21] K. H. Bak, T. Bolamar, A. H. Karlsson, G. Lindahl, and V. Orlien, "Effect of high pressure treatment on the colour of fresh and processed meats: A review," Critical Reviews in Food Science and Nutrition, pp. 1-25, 2017. View at Google Scholar $\mid$ View at Publisher

[22] S. C. Bestos, M. E. S. Pimenta, C. J. Pimenta, T. A. Reis, C. A. Nunes, P. A.C.M., L. F. F. Fabricio, and R. S. Leal, "Alternative fat substitute for beef burger: Technological and sensory characteristics," Journal of Food Science and Technology, vol. 51, pp. 20462053, 2014. View at Google Scholar | View at Publisher 